Association for Information Systems

AIS Electronic Library (AISeL)

\title{
Opening the Minds of Upper Secondary School Students for Business Informatics: an Exploratory Study and an Outline for a Dedicated Teaching Program
}

\author{
Carola Schauer \\ Universität Duisburg-Essen \\ Hanno Schauer \\ Mons-Tabor-Gymnasium
}

Follow this and additional works at: https://aisel.aisnet.org/wi2021

Schauer, Carola and Schauer, Hanno, "Opening the Minds of Upper Secondary School Students for Business Informatics: an Exploratory Study and an Outline for a Dedicated Teaching Program" (2021). Wirtschaftsinformatik 2021 Proceedings. 7.

https://aisel.aisnet.org/wi2021/YGeneralTrack/Track02/7

This material is brought to you by the Wirtschaftsinformatik at AIS Electronic Library (AISeL). It has been accepted for inclusion in Wirtschaftsinformatik 2021 Proceedings by an authorized administrator of AIS Electronic Library (AISeL). For more information, please contact elibrary@aisnet.org. 


\title{
Opening the Minds of Upper Secondary School Students for Business Informatics: an Exploratory Study and an Outline for a Dedicated Teaching Program
}

\author{
Carola Schauer ${ }^{1}$, Hanno Schauer ${ }^{2}$ \\ ${ }^{1}$ University Duisburg-Essen, Institute for Computer Science and Business Information \\ Systems, Research Group for Information Systems and Enterprise Modelling, Essen, Germany \\ carola.schauer@uni-due.de \\ ${ }^{2}$ Mons-Tabor-Gymnasium, Montabaur, Germany \\ hanno.schauer@mtg-mt.de
}

\begin{abstract}
Graduates of Business Informatics (BI) have excellent job perspectives. The ongoing digital transformation entails the fascinating opportunity for our students to participate in designing future organizations. At the same time, enrollment statistics for German universities indicate relatively low first-yearstudent numbers in BI bachelor's degree programs. Personal experience additionally suggests that many first-year-students have no clear idea about BI and their future role in practice. Hence, we assume that the perception of BI by secondary schools students is already biased by substantial misconceptions. This paper intends to contribute to the debate on how to raise the awareness of upper secondary school students for study programs in BI. Based on an exploratory survey and practical experience through a case study teaching program employed by "school ambassadors", we propose critical success factors for designing initiatives to disseminate a realistic and attractive image of $\mathrm{BI}$ and the professional perspectives it enables.
\end{abstract}

Keywords: Business Informatics, Student Perceptions, Secondary Schools

\section{$1 \quad$ Motivation and Objectives}

In virtually all industries, business enterprises are exploring ways to deal with the challenges and opportunities that arise from a continued increase in digitalization. Designing information systems for businesses and organizations using digital technologies has for decades been the subject of research of the field of Business Informatics (BI) ${ }^{1}$ ("Wirtschaftsinformatik") in the German speaking countries (e.g. [1], [2]).

1 In this paper we use "Business Informatics" as a literal translation of "Wirtschaftsinformatik", because we find this to be better suited to translate our research activities, which have been conducted in German with students at schools in Germany. Information Systems is commonly known as the international equivalent of the discipline "Wirtschaftsinformatik" in German speaking countries.

16th International Conference on Wirtschaftsinformatik, March 2021, Essen, Germany 
University study programs in BI prepare students for acting as mediators between the different stakeholders participating in and affected by IT innovation projects. For years there has been a continually high demand for BI graduates in German speaking countries [3]. Respective study programs seek first-year students, who show sufficient interest and capacity for successfully completing their studies. As members of a BI Institute at a large University in North-Rhine-Westphalia (NRW), Germany, we have the impression, that many of our first-year students choose our study program with inadequate assumptions about the field in mind. Additionally, we feel that there is a great potential among the secondary school students that is currently not realized. Thus, being aware of a constantly high demand for BI graduates on the job market and a successful and application oriented academic field of BI, we ask ourselves why firstyear-student numbers and students' conceptions about their field of study are unsatisfactory.

Secondary schools are in their current state likely not capable of fulfilling the requirements necessary to solve this problem (see section 2). The shortage of students creates a threat to research in BI, because it is likely to lead to an insufficient number of graduates, who are interested in pursuing a $\mathrm{PhD}$. Research addressing the specific challenges of the field of BI to attract adequate first-year-students is rare (see section 0 ). Thus, it seems advisable, in the discipline's own interest, that the academic field directs more attention to this situation and starts to explore approaches to foster the field's perception among secondary school students.

The intention of this paper is to serve as a starting point to improve the perception of BI among prospective university students by (1) exploring how secondary II level students perceive the university study program BI and (2) formulating requirements for initiatives on how to better address the field's characteristics and relevance at schools.

While this article is based on experience with students in Germany and the specific situation of BI, it addresses a gap also perceived in international Information Systems study programs (e.g. [4], [5], [6]). Albeit, the rapid decline in enrollments that struck Management Information Systems programs after 2000 [7], has not as much affected the more application oriented BI programs in German speaking countries (cf. [2]).

This paper is structured as follows: In order to derive an initial hypothesis and research questions section 2 looks at the status of school curricula and evaluates firstyear-student numbers in Germany. Section 0 provides an overview of related work on existing initiatives for informing students about BI or Information Systems study programs. In section 4 we report on results of an exploratory survey of secondary II level students to inquire their perceptions about the field of BI. Section 5 presents a case based teaching program for secondary II level classes and reports on practical experience at schools. In the final section, we formulate conclusions and propose requirements for future initiatives based on our exploratory study results and practical experience (section 6). 


\section{Current status: Secondary School Subjects and First-Year- Student Numbers}

Various factors can influence the choice of a study program, including parents or friends and informative events at schools or universities. In the best case, insights about a prospective future study program can be gained in a structured manner, when a school subject is taught that relates to the corresponding academic field. For the field of BI, possibly corresponding school subjects are Business Administration ("Wirtschaft"), Computer Science ("Informatik"), and Business Informatics ("Wirtschaftsinformatik").

In Germany, federal states are responsible for educational policy. We focus on NRW and its secondary school system. In NRW Business Administration and BI are mandatory subjects at "Wirtschaftsgymnasien" and vocational schools [8]. Both subjects are not part of the current curriculum at general secondary schools. For many years, Computer Science has been an elective subject at secondary schools. Thus, only a relatively small fraction of each age group actually attends Computer Science classes [9]. In several states in Germany, including NRW, compulsory Computer Science courses have recently been or will in short time be introduced to lower secondary school grades.

There have been recent curriculum changes beyond Computer Science classes: In NRW curricula of various school subjects have been adjusted to include topics on digitalization [10]. Remarkably, all respective changes to the curriculum relate to lower secondary classes only. Furthermore, the curricula changes to these non-computing subjects primarily address issues pertaining to the use of information technology devices and applications, but not to their design. Hence, despite all recent curriculum initiatives in NRW to better prepare students for the digital world, there is still a considerable lack of dedicated support for, in particular, upper secondary students to learn about the challenges and opportunities of the increasing digitalization.

Against this background and based on anecdotal evidence we assume that the discipline of $\mathrm{BI}$ is either not known or is connected with misleading ideas by secondary II level students in Germany (hypothesis I). We derive two research questions that will be addressed in the following sections:

\section{RQ 1: What are the perceptions of secondary II level students towards BI?}

RQ 2: To what extent do the perceptions vary between students who have attended Computer Science classes at school and those who have not?

Assuming that first-year student numbers are an indicator for secondary school graduates' interest in the field, we analyzed statistical data provided by the German census bureau for the most recent study year (2018). Analysis results indicate - compared to Business Administration and Computer Science - relatively low numbers of first-year students, particularly in university study programs for BI.

Figure 1 differentiates the available data on first-year-students according to different education institution types: universities with traditional on campus classes, distance universities, Fachhochschulen (Universities of Applied Sciences) with full-time study 
programs as well as other Fachhochschulen who offer study programs that do not require full-time studying (e.g. distance, dual or on the job, part-time).

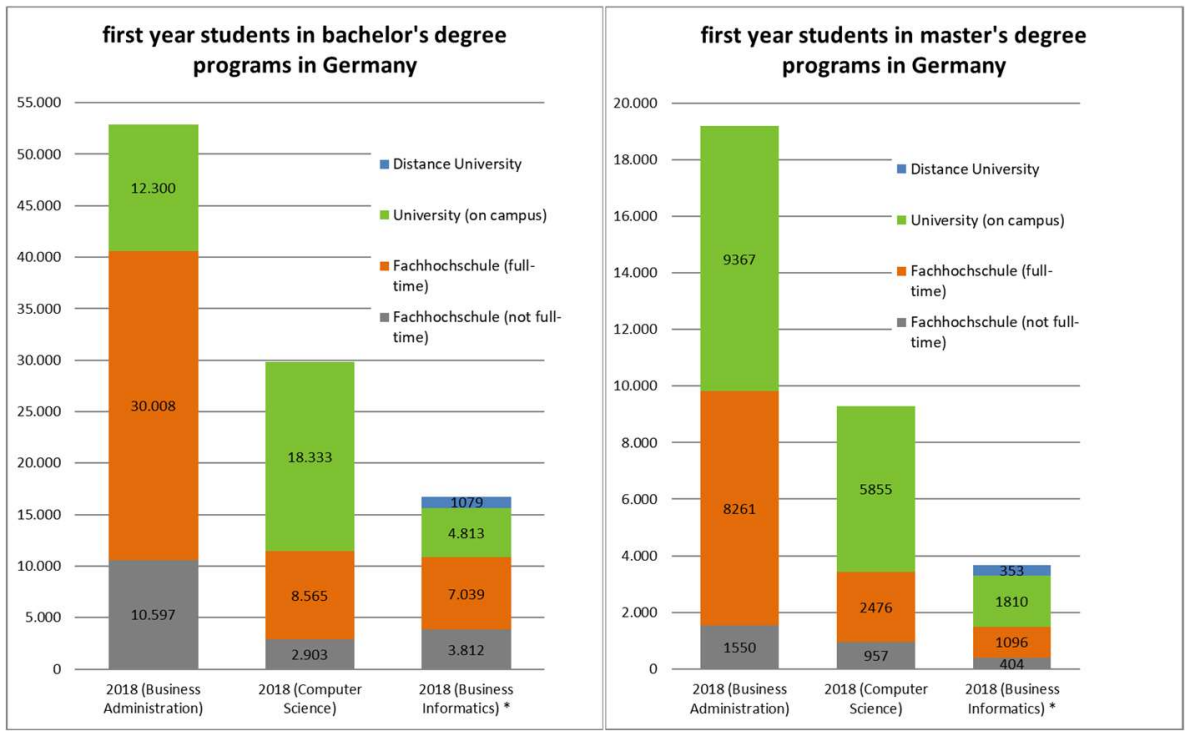

* With respect to BI ("Wirtschaftsinformatik"), the census data are incomplete: there are six universities with BI programs that are not included. Therefore, 510 University first-year-students in bachelor's programs and 135 first-year-students in university master's programs have been added to the census data (based on CHE data for study year 2019 [13]).

Figure 1. Comparison of first-year-student numbers per field enrolled at Fachhochschulen and universities in Germany (source: Statistisches Bundesamt)

Compared to universities there have been twice as many first-year students starting a BI bachelor's degree at Fachhochschulen in 2018. These results affirm the conclusions of Hachmeister, who analyzed data from 2017 on Informatics study programs in Germany [11]: Compared to all other Informatics related study programs, BI has the highest rate of ,dual“, part-time, and distance study programs offered by Fachhochschulen which are frequently pursued while doing a full-time job ([11], p. 21).

Even when only considering full-time BI degree programs, Fachhochschulen are apparently outnumbering universities in terms of first-year-student numbers at undergraduate level. Conversely, on master's level there are about twice as many first-year-students enrolled at university BI programs compared to Fachhochschulen. The statistics on student numbers indicate that universities are experiencing a tough competition with Fachhochschulen in particular on the bachelor's level (cf. [12]).

Hence, the question remains, what can be done to attract more students to BI university programs? Assuming that students' perceptions are currently biased by severe misconceptions about BI, we intend to develop a dedicated teaching program. To this end we formulate the third research question:

(RQ 3): What are the requirements for a successful teaching program to inform secondary II level students about academic BI study programs at universities? 


\section{Related Work}

An intensive Internet and literature search revealed one documented initiative specifically aimed at informing secondary school students about the characteristics of BI study programs: A coalition of Fachhochschulen developed the "WI case", a collection of teaching materials and games related to BI for secondary school students. A paper describing the development and the objectives was published in 2016 [14]. Further initiatives driven by individual BI institutions might exist, but have - according to our knowledge - not yet been publicly reported.

Several initiatives aimed at attracting new students are documented for the German Computer Science discipline (see proceedings of the biannual conference HDI "Hochschuldidaktik der Informatik", e.g. [15]). In 2013 an article was published describing the concept of "Informatics ambassadors", i.e. graduates who visit schools to inform about the study program "Informatics", implemented at the HTW Berlin College [15]. So far, no more recent publication could be found discussing experience of applying the approach.

In 2008 Thonabauer and Mayr published an article reflecting gender issues in the German BI field. They see a need for initiatives, e.g. certain topics and female role models in order to make BI a more attractive study choice for female students [16].

At secondary schools in Germany, there have been many projects and initiatives to acquaint female students with the MINT ${ }^{2}$ areas. Several studies revealed that role models can be an effective means to attract female students [17]. Reports about successful female role model initiatives include projects targeted at Informatics or BI [18].

Anderson et al. provide an overview of various initiatives at universities in the US to encourage more female undergraduates to major in Information Systems. Experimental teaching settings as part of an introductory Information Systems (IS) class aimed at convincing more female students to choose IS as a major. However, the initiatives' results are rather disillusioning: "none were effective in encouraging more female students to consider majoring in IS" [19].

Vainionpää et al. recently published a literature review analyzing existing studies on the low number of women in IT related study programs and jobs [6]. They summarize, that "despite all good work of different actors to entice young women to consider the IT field as a welcoming career choice, the situation seems to be going to even worse direction as the decreasing number of women working in the IT field shows." ([6], p. 13). They conclude that in order to arouse children's interest for the field of IT/IS we need to better "link our efforts to children's life worlds" ([6], p. 13).

2 The acronym MINT (Mathematik, Informatik, Naturwissenschaften, Technik) is the German counterpart to STEM (Science, Technology, Engineering, Mathematics) in English speaking countries. 


\section{Exploratory Study: Perceptions and Misperceptions about BI}

We developed a survey for secondary II level students intended as a means to get a clearer idea of their perception concerning the academic field of BI by exploring research question RQ 1 and RQ 2.

The survey instrument was tested in March 2018 by two secondary II level students using a preliminary paper based questionnaire. Necessary adjustments were made for higher clarity and understandability of the terms used in the questions. The survey was subsequently implemented and pilot tested by two bachelor's students using LimeSurvey. The questions considered in this article are part of the online questionnaire that takes about 10 to 15 Minutes to complete.

We deliberately chose open questions in order to allow the participants to use their own words when describing their perceptions [20]. The questions asked were: "What is your current perception of the study subject of BI?" and "According to your impression: how good are the job perspectives of BI university graduates?"

The results interpreted in this article are based on 331 questionnaires completed between November 2018 and March 2020. All survey participants were secondary II level students at 18 different schools in NRW, who were later visited by our school ambassadors (see section 5).

Of the 331 participants $40 \%$ (134) are female and $56 \%$ (187) male (10 chose to provide no answer to gender). The majority of the participating students (79\%) stated to have attended a Computer Science class. 70 participants (21\%) stated to have never been in a Computer Science class before.

\subsection{Classification of Answer Statements}

In the spirit of an exploratory study, we deliberately did not pursue the answer analysis with a pre-structured classification scheme in mind. In order to evaluate the answers, we performed a hermeneutic text analysis and successively identified groups of similar answers. After reading all statements on the participants' current perception about BI, sixteen first level categories were identified as appropriate to classify all given statements (see Table 1). In a second step, the first level categories were grouped to six higher-level categories. Figure 2 depicts the shares of each higher-level category.

The largest group of the participants $(42 \%)$ stated not to have any idea about the field BI (red). The red colored area also includes the answers that only vaguely describe that the field is somehow about "Business" ("Wirtschaft") and "Informatics" ("Informatik") (13\%).

We assessed $13 \%$ of the answers as positive (light green), because they include statements that express either interest in the field, assess it as challenging and/or effortful, or describe a relevant topic (incl. digitalization in businesses, intermediator role of the field, business software systems). Additionally, $6 \%$ of the statements are classified as acceptable (green), because they entail appropriate statements about a selected area in the field, but are rather one-sided. For example, this category includes 17 statements expressing that $\mathrm{BI}$ focuses on the analysis of economic data. 
Table 1. Derived groups of categories for answer statements

\begin{tabular}{|c|c|}
\hline Summarized categories & $\begin{array}{c}\text { \# of } \\
\text { stmts. }\end{array}$ \\
\hline $\begin{array}{c}\text { Informatics is less important, more busi- } \\
\text { ness/economics }\end{array}$ & 7 \\
\hline $\begin{array}{c}\text { Primarily Programming/Computers, less } \\
\text { business }\end{array}$ & 23 \\
\hline a lot mathematics & 9 \\
\hline a lot computers & 11 \\
\hline $\begin{array}{c}\text { a lot theory } \\
\text { not interesting for me }\end{array}$ & 6 \\
\hline no idea & 21 \\
\hline "Business" and "Informatics" & 44 \\
\hline other (incl. comparison to school subject \\
"Business Informatics") & 9 \\
\hline
\end{tabular}

\begin{tabular}{|c|c|}
\hline Summarized categories & $\begin{array}{c}\text { \# of } \\
\text { stmts. }\end{array}$ \\
\hline $\begin{array}{c}\text { specific: data analysis using IT (eco- } \\
\text { nomic data) }\end{array}$ & 17 \\
\hline $\begin{array}{c}\text { specific: software sales/marketing/con- } \\
\text { sulting }\end{array}$ & 4 \\
\hline $\begin{array}{c}\text { interesting } \\
\text { challenging, effortful }\end{array}$ & 9 \\
\hline $\begin{array}{c}\text { specific: digitization in businesses, pro- } \\
\text { cess orientation }\end{array}$ & 11 \\
\hline Intermediator between business and IT & 3 \\
\hline business software systems & 10 \\
\hline
\end{tabular}

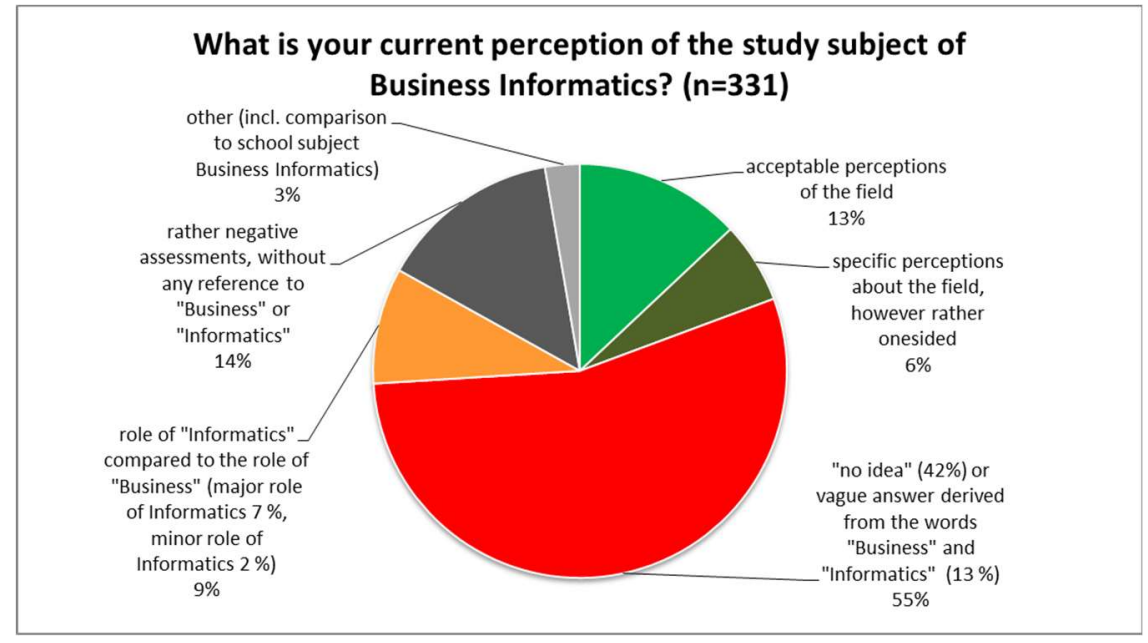

Figure 2. Results on perception about the study subject of BI

We see varying statements concerning the role of programming or Computer Science in the field (orange): while a few state that Informatics plays only a minor role (7), a greater number of participants expresses that programming and Computer Science plays a major role in the field (23). $14 \%$ of the statements entail only a brief, rather negative statement (dark grey), such as "a lot mathematics/computers/theory". $6 \%$ of the participants expressed, that they are not interested in the field.

When we focus on the statements made by students who have never attended a Computer Science class at school, we see even more clearly the lack of knowledge about the field. Almost $60 \%$ of those students state to have "no idea" about the field. Only $3 \%$ 
of the statements in this group include an acceptable assessment of the field's characteristics. There is, however, a number of students $(10 \%)$ who name a specific selected topic in our field (such as analysis of economic or business data).

The majority of the participating students formulate positive statements when asked for the job perspectives of future university graduates in the BI field: $62 \%$ wrote "good" or "very good". However, even among those who have attended Computer Science classes at school, $24 \%$ expressed to have "no idea" about the job perspective of BI graduates. This rate is even higher $(33 \%)$ in the group of those students who have not attended a Computer Science class at school.

\subsection{Discussion of Survey Results and Requirements for a Teaching Program}

The results of the interpretative text analysis support hypothesis I. While this is not surprising at first, we could also identify various aspects with regard to RQ 1 and RQ 2:

- A large proportion (40\%) of the surveyed students states to not have any idea about the field; in the group of those who have not attended a Computer Science class, the proportion is even higher $(60 \%)$. Hence, we can constitute a severe perception or knowledge gap concerning the field BI even among those who attended Computer Science classes at schools.

- Many answers stay vague, just repeating the words "Business" and "Informatics". Few answers indicate an understanding of the role of IT in organizations. Only about one fifth of all survey participants formulate a perception of the field's characteristics using appropriate terms.

- Notwithstanding the omnipresent digitalization topic, about one third of the surveyed students describe BI job perspectives with "not so good" or "no idea".

In consequence, we argue for the need of efforts in the BI field aimed at addressing the misconceptions and knowledge gaps among secondary students. We acknowledge that this includes not only a teaching program but also pertinent changes in educational policy.

Our survey results and the analysis of prior studies (see section 0) lead us to the following requirements for a dedicated teaching program for upper secondary classes (RQ 3):

Subject: Teaching concepts should convey a realistic picture (1) of the important role of digitalization in organizations now and in the future, (2) of the field of BI in business practice, and (3) of the specific qualities and requirements of university study programs in BI.

Target group: Initiatives should be directed not only at Computer Science classes but also at students, who have not attended Informatics related classes.

Means: Teaching concepts should connect properly to the students' life world [6]. We suggest that using role models, i.e. former students, who share life and school experience with the target group, can be helpful to better connect to students. Secondary school students apparently have difficulties imagining the role of IT and digital innovations for society and industry. Using case studies in combination 
with narratives seems a promising approach to help students overcome their current limited perception concerning our field and allow for imagining the possible worlds that can be created with IT innovations ([21], [22]).

\section{$5 \quad$ A Case Study based Teaching Approach}

We developed a case study based teaching program for upper secondary school classes. The program was designed and tested in school practice by the authors. Reflecting the challenge of getting access to the target group in a way that is perceived as authentic and interesting, we decided to set up and test a school ambassador program: undergraduate and graduate university students of BI volunteered and were specifically trained as school ambassadors to employ the case study with learners at their former schools.

Using the case study method, the ambassadors address not only those who are interested in a particular study program but all learners: The case study is directed at enhancing their competencies of critically reflecting and analyzing the challenges and opportunities in the digital world. Hence, this case study based teaching concept is also an explorative approach to address the lack of teaching digitalization issues in upper secondary classes in NRW (see section 2).

The teaching concept pursues three major learning objectives, adhering to a designoriented constructive view on digitalization typical for the German BI discipline (cf. [33], [34], [35]). The learners are to be enabled to understand the following three aspects:

1. Multiplicity of perspectives: the perspectives of various stakeholders should be taken into account when analyzing the potential benefits and costs of IT innovations in organizations.

2. Central role of structuring: in order to analyze opportunities and challenges of IT in organizations, it is basal to identify appropriate technical concepts or terms of the domain to structure the analysis.

3. IT affects action systems: introducing new IT in an organization does not only change the technology available for the different stakeholders but also allows new creative ways to design actions, workflows and processes, hence the organization itself.

The case study is embedded in a sequence of presentations tailored to a 90 -minute class. During the opening phase, the ambassadors briefly describe their own educational background. After the completion of the case study, the ambassadors present the specifics of the bachelor's study program and explain differences to neighboring fields (Business Administration, Computer Science) and to Fachhochschulen.

\subsection{Role of the Case Method in Teaching and Requirements for Success}

On university level, case based teaching has early been applied in medicine and law courses, and, later, in business graduate schools. Its practical application in business 
classes at Harvard School is documented by Jackson [23]. Many cases have been developed, published and applied in classes since the early twentieth century ([24], p. 15). Case study based teaching methods are nowadays commonly applied in business school graduate courses (see e.g. [25], [24]). More recent publications document their use in undergraduate business classes [26]. Meanwhile, computing disciplines have adopted case based teaching approaches as well (e.g. [27], [28], [29]). At secondary school level, the case study ("Fallstudie" in German) is known as a didactical method allowing learners to develop self-contained problem solving abilities (e.g. [30] p. 36 ff; [31] p. $257 \mathrm{ff}$ ).

In his early accounts on the practice of the case method at Harvard University Jackson explains that a case gives insights into the procedure or method applied to tackle a problem by a certain role in the organization ([23], p. 110). Burgoyne and Mumford extend this early account by emphasizing the role of group work and learner discussions on an initially presented situation that should be further developed ([24], p. 14).

Specifically, the case-study based teaching approach allows the learners

- to analyze complex real-life problems from multiple viewpoints (see e.g. [26], p. 343), thus explicitly supporting learning objective 1,

- to identify and apply useful structures and terms in group discussions and presentations, thus supporting learning objective 2 , and

- to reflect upon certain roles, their activities and methods (see e.g. [31]), thus addressing learning objective 3 as well.

Understanding the opportunities and possible effects of digitalization in organizations is a challenging task in particular for learners who have little knowledge in business and/or computing. A case based approach with an introductory narrative, therefore, seems a promising instrument to help learners to reflect on existing and imagine future digital innovations in organizations.

\subsection{Case Study Teaching Program: "Digitalization in classes at Konrad- Adenauer-Gymnasium"}

So far, at general-education schools in NRW there is no subject on business economics. Hence, knowledge related to roles and processes in private businesses cannot be assumed as given. Secondary school students are, however, usually familiar with the different roles and processes at their own school. Moreover, investment decisions in the schools' information technology infrastructure have been a current topic at every school in Germany, starting in 2019 because of the federal "DigitalPakt" funding program for schools [32]. Hence, a case study on digitalization at an exemplary school is an up-todate and highly relevant topic in the students' life world, that we expect learners as well as school teachers to connect to easily. Therefore, we chose a general public school, the fictitious Konrad Adenauer Gymnasium (KAG), as object of our case study.

The case study teaching concept comprises several steps (see Table 2): an introduction of the case situation, a structured analysis phase, and a final discussion in a simulated teachers' meeting. Depending on the prior knowledge of the participating learners as well as class size, the teaching concept is planned to take between 45 and 60 minutes. 
Table 2. Main steps of the case study including roles and didactical means.

\begin{tabular}{|l|l|l|l|}
\hline$\#$ & who (role) & what (learning content) & how (didact. means) \\
\hline 1 & $\begin{array}{l}\text { ambassador as school } \\
\text { principal }\end{array}$ & $\begin{array}{l}\text { Introduction of the case at KAG, consult- } \\
\text { ing task: “Analyze potential benefits and } \\
\text { costs of enhancing IT in classes." }\end{array}$ & $\begin{array}{l}\text { presentation } \\
(2 \text { min.) }\end{array}$ \\
\hline 2 & $\begin{array}{l}\text { ambassador as leading } \\
\text { consultant, } \\
\text { students as consultants }\end{array}$ & $\begin{array}{l}\text { Analysis I: identify interest groups } \\
\text { Analysis II: substantiate the term infor- } \\
\text { mation technology }\end{array}$ & $\begin{array}{l}\text { discussion } \\
(5-8 \text { min) }\end{array}$ \\
\hline 3 & $\begin{array}{l}\text { ambassador as leading } \\
\text { consultant }\end{array}$ & $\begin{array}{l}\text { Analysis III: } \\
\text { basic structure of application areas for } \\
\text { digitization in classes }\end{array}$ & $\begin{array}{l}\text { presentation and } \\
\text { class discussion } \\
\text { (5 min) }\end{array}$ \\
\hline 4 & $\begin{array}{l}\text { students as consultants } \\
\text { viewalyze digitization areas from the } \\
\text { group }\end{array}$ & $\begin{array}{l}\text { discussion in groups, } \\
\text { group presentations } \\
\text { (25-35 min) }\end{array}$ \\
\hline 5 & $\begin{array}{l}\text { ambassador as critical } \\
\text { school principal, } \\
\text { students as consultants }\end{array}$ & $\begin{array}{l}\text { Teachers' meeting: a critical statement is } \\
\text { given, students are asked to provide a well- } \\
\text { grounded and justified answer }\end{array}$ & $\begin{array}{l}\text { discussion } \\
\text { (5 -10 min) }\end{array}$ \\
\hline
\end{tabular}

\subsection{Preliminary Evaluation through Practical Experience}

Between November 2018 and March 2020 twelve of our students volunteered as ambassadors and employed the case study in 22 lessons with upper secondary learners. The ambassadors reached 491 students at 18 different schools in NRW. About $30 \%$ of the participating learners were female.

Up to two classes participated in each lesson during the regular school hours with two visiting ambassadors acting as lecturers. In most cases the teacher, who scheduled the ambassadors' visit at his or her school, was a former teacher of one of the visiting ambassadors. $50 \%$ of the participating courses were Computer Science classes. Several other subject teachers had shown interest in the program as well. Hence, the classes visited include Mathematics, Natural Science, Social Science and Business Informatics classes (at a "Wirtschaftsgymnasium").

For evaluation purposes the ambassadors were asked to provide a personal account of each visit (as a voice message or a brief text) assessing the students participation and the success of the case study in class. The following brief evaluation is based on the ambassadors' reports as well as on the authors' own experience in classes.

For all lessons performed at the different schools, the ambassadors expressed that the case study could be completed successfully: the analysis steps, the group work, and presentations were carried out by the learners and learning objectives were addressed by the learners themselves or the ambassadors. Several teachers actively participated in the case study apparently out of personal interest in the case. Several teachers positively acknowledged the high student activity in the teaching concept.

Our school ambassadors are not professionally educated teachers, but specifically trained and highly motivated (under-)graduate BI students. However, the special role of the ambassadors as school alumni and role models for the learners apparently facilitated a fruitful learning atmosphere in most classes - an important requirement for achieving good learning results with case studies ([25], [26]). 
In our experience, the participation of learners in class discussions does not depend on the course subject. The ambassadors reported fruitful class discussions and differentiated analysis results in Computer Science Classes and in other classes as well. However, we perceived that attentive teachers in class positively affected the learning atmosphere as well as the learners' participation in several classes.

While the participating teachers from non-Computing subjects have shown general interest in the case study, the learners in three of these six courses showed rather disparate levels of contribution to class discussion. Therefore, we are planning to extend the case study to include special analysis questions and teaching material for different subjects aimed at increasing the learners' perceived relevance of the case study.

\section{Conclusions and Future Work}

Digitalization in businesses and organizations are the core of the BI discipline in German speaking countries. Our explorative study suggests a considerable lack of understanding and misperceptions about the field of BI among secondary II level students (hypothesis I, RQ 1, RQ 2). We developed a case study based teaching approach in order to address the identified need to open and change the mind of prospective students. Founded on educational principals and requirements we chose an explorative way through practical experience in secondary school classes to assess the adequacy of the chosen approach (RQ 3).

Although the effectiveness of our case study based teaching program has not yet been formally evaluated, based on practical lessons learned we suggest several requirements and potential success factors. These should be understood as preliminary propositions intended to serve as a basis for designing future initiatives for informing secondary school students about the field of BI:

Case study teaching concepts are promising, but should be flexible to adapt to different levels of discourse and take into account student knowledge conveyed by different school subjects. For example, a class discussion should be on a relatively high level of abstraction for Social Science classes with routine in critical discourse while more structuring is advisable in a Computer Science class with little experience in presentations and discussions.

Narratives can serve as a vivid means to connect to secondary school students and attract attention. A colorful narrative to introduce the case study and simulate a teachers' conference motivates students to participate more actively, because it helps to better understand the problem situation and tasks at hand. Ambassadors acting as role models can embed stories about their own experience. These narratives are helpful for the learners to get a feeling for the yet unknown situation of being a BI university student.

Schools are generally willing to cooperate and invite ambassadors. Out of 20 schools that were offered a visit, 17 accepted the offer, leading to an acceptance rate of $85 \%$. The majority of schools visited is looking forward to organizing annual or biannual ambassador visits. 
Motivated BI students, who already understand their future role as mediators, are promising role models. In our experience, many students are motivated to act voluntarily as ambassadors at their own school and at other schools as well. Authenticity in class, however, requires a prior critical reflection of personal decisions and assessments. A differentiated understanding of the specifics of BI is a prerequisite for ambassadors to authentically lead the discussion and adequately react to the learners' arguments.

Testing the teaching concept with the target group and implementing an ambassadors' training concept is crucial in order to enable the ambassadors to apply it successfully in practice. Perceived effective visits are an important factor to retain ambassadors and motivate them for further visits.

The proposed teaching program requires considerable efforts for developing teaching material, training ambassadors and scheduling regular visits to schools. Its reach in terms of visited schools and students is rather limited for a single institution. Hence, it seems advisable to strive for a coordinated project in the BI community to take advantage of synergy effects. A respective draft should take into account the competitive situation of individual institutions.

Since digitalization is increasingly affecting the planning and practice of businesses and organizations across all industries, preparing all secondary II level students as critical (future) designers and planners of digitalization seems an important objective of future research in BI (cf. [6]). Thus, we view our contribution in this paper not only as a practical report about an initiative to attract new BI-students, but also as a first step towards BI teaching concepts for upper secondary school classes.

\section{References}

1. Legner, C., Eymann, T., Hess, T., Matt, C., Böhmann, T., Drews, P., Mädche, A., Urbach, N., Ahlemann, F.: Digitalization: Opportunity and Challenge for the Business and Information Systems Engineering Community. Bus Inf Syst Eng 59, 301-308 (2017)

2. Frank, U., Schauer, C., Wigand, R.T.: Different Paths of Development of Two Information Systems Communities: A Comparative Study Based on Peer Interviews. Communications of the Association for Information Systems 22 (2008)

3. Schauer, C., Frank, U.: Wirtschaftsinformatik und Information Systems. In: Lehner, F., Zelewski, S. (eds.) Wissenschaftstheoretische Fundierung und wissenschaftliche Orientierung der Wirtschaftsinformatik, pp. 121-154. GITO-Verl., Berlin (2007)

4. Iivari, N., Molin-Juustila,, T., Kinnula, M.: The future digital innovators: empowering the young generation with digital fabrication and making. In: ICIS 2016 Proceedings

5. Elder, K.L., Goette, T., MacKinnon, R.: A METHOD TO INCREASE IS ENROLLMENTS. Issues in Information Systems (2019)

6. Vainionpää, F., Kinnula, M., Iivari, N., Molin-Juustila, T.: GIRLS' CHOICE - WHY WON'T THEY PICK IT? Research Papers (2019)

7. Saunders, Gary|Lockridge, T. Maurice: Declining MIS Enrollment: The Death of the MIS Degree? Contemporary Issues in Education Research 4, 15-26 (2011) 
8. Schauer, C., Frank, U.: Wirtschaftsinformatik an Schulen. DuEPublico: Duisburg-Essen Publications Online, University of Duisburg-Essen, Germany (2018)

9. Schauer, C., Schauer, H.: IT an allgemeinbildenden Schulen: Bildungsgegenstand und infrastruktur. ICB Research Reports (2019)

10. Ministerium für Schule und Bildung, NRW: Ministerin Gebauer: Landesregierung bringt Einführung der Fächer Wirtschaft und Informatik für alle Schulformen auf den Weg (2019)

11. Hachmeister, C.-D.: Frauen in Informatik: Detaillierte Ergebnisse der Strukturanalyse. Gütersloh (2018)

12. Loos, P., Clarner, R., Hermann, F., Hess, T., Gadatsch, A., Sinz, E.: Business and Information Systems Engineering Programs at Universities and Fachhochschulen - Convergence or Differentiation? Bus Inf Syst Eng 5, 281-286 (2013)

13. CHE Hochschulranking: Ranking für Wirtschaftsinformatik, https://ranking.zeit.de/che/de/

14. Ketterer, N., Kuhn, E., Meister, V.G., Röckle, H.: MARKETING FÜR EIN WIRTSCHAFTSINFORMATIK- STUDIUM MIT HILFE DES „WI-KOFFERS“. Anwendungen und Konzepte der Wirtschaftsinformatik, 1-8 (2016)

15. Göttel, T.: Schnupperveranstaltungen Informatik in der Hochschullandschaft. In: Forbrig, P., Rick, D., Schmolitzky, A. (eds.) HDI 2012 - Informatik für eine nachhaltige Zukunft. 5. Fachtagung Hochschuldidaktik der Informatik ; 06.-07. November 2012, Universität Hamburg, pp. 45-55. Univ.-Verl. Potsdam, Potsdam (2013)

16. Thonabauer, C., Mayr, D.: Gender Mainstreaming in der Wirtschaftsinformatik. HMD 45, 105-115 (2008)

17. Augustin-Dittman, S., Gotzmann, H. (eds.): MINT gewinnt Schülerinnen. Erfolgsfaktoren von Schülerinnen-Projekten in MINT. Springer VS, Wiesbaden (2015)

18. Battistini, M.: Ganz normale Exotinnen. In: Augustin-Dittman, S., Gotzmann, H. (eds.) MINT gewinnt Schülerinnen. Erfolgsfaktoren von Schülerinnen-Projekten in MINT, pp. 93-110. Springer VS, Wiesbaden (2015)

19. Anderson, L., Edberg, D., Reed, A., Simkin, M.G., Stiver, D.: How Can Universities Best Encourage Women to Major in Information Systems? CAIS 41, 734-758 (2017)

20. Fink, A.: How to ask survey questions. Sage Publ, Thousand Oaks, Calif. (2003)

21. Alvarez, R., Urla, J.: Tell me a good story. SIGMIS Database 33, 38 (2002)

22. Frank, U.: Theories in the Light of Contingency and Change: Possible Future Worlds and Well-Grounded Hope as a Supplement to Truth. In: Hawaii International Conference on System Sciences (HICSS-50), 2017. January 4-7, 2017, Waikoloa Village, Hawaii. AIS Electronic Library (AISeL), Erscheinungsort nicht ermittelbar (2017)

23. Jackson, H.J.: The Case Method. The Accounting Review 1, 108-111 (1926)

24. Burgoyne, J., Mumford, A.: Learning from the Case Method Department of Management Learning, Lancaster University Management School, A report to the European Case clearing house (2001)

25. Bruner, R.F., Gup, B.E., Nunnally Jr., B.H., Pettit, L.C.: Teaching with cases to graduate and undergraduate students. Financial Practice and Education, 111-119 (1999)

26. Trejo-Pech, C.J.O., White, S.: The use of case studies in undergraduate Business Administration. Rev. adm. empres. 57, 342-356 (2017) 
27. Harper, J.S., Lamb, S.W., Buffington, J.R.: Effective Use of Case Studies in the MIS Capstone Course through Semi-Formal Collaborative Teaching. Journal of Information Systems Education 19, 411-418 (2008)

28. Varma, V., Garg, K.: Case studies: the potential teaching instruments for software engineering education. In: Fifth International Conference on Quality Software (QSIC'05), pp. 279-284 (2005)

29. Daun, M., Salmon, A., Weyer, T., Pohl, K., Tenbergen, B.: Project-Based Learning with Examples from Industry in University Courses: An Experience Report from an Undergraduate Requirements Engineering Course. In: Proceedings of IEEE 29th International Conference on Software Engineering Education and Training (CSEET), pp. 184-193 (2016)

30. Zendler, A.: Unterrichtsmethoden: Steckbriefe, Prozessmodelle und Beispiele. In: Unterrichtsmethoden für MINT-Fächer, pp. 21-78. Springer Fachmedien Wiesbaden, Wiesbaden (2018)

31. Frey, K., Frey-Eiling, A.: Ausgewählte Methoden der Didaktik. vdf Hochsch.-Verl. an der ETH, Zürich (2010)

32. Verwaltungsvereinbarung: DigitalPakt Schule 2019 bis 2024 (2019) 